によって Cu-Be素線も十分に磁性線の素地として適用で きることが明らかとなった。

$$
\text { (1973-3-28 受理) }
$$

（昭和45年 5 月，本協会第41回学術講演大会にて発表）

$$
\text { 文献 }
$$

1) 大野, 他, 本誌, 15, 48 (1964)

2）大野, 他, 同上, 16, 52 (1965)
3) 戸田，他，同上，16，241（1965）

4）大野, 他, 同上, 17, 465 (1966)

5) 大野, 他, 同上, 18, 86 (1967)

6) 大野, 他, 同上, 19, 201 (1968)

7）大野, 他, 工化誌, 72, 545 (1969)

8 ) R. M. Shemenski, et al., J. Electrochemical Technology, 116, 402 (1969)

\title{
人工海水中におけるアルミニゥム合金の流電陽極試験
}

\author{
田村寿康 ${ }^{*} \cdot$ 佐藤栄一** ・岡部泰二郎 ${ }^{* *}$
}

\section{Galvanic Anode Tests of Al-Zn, Al-Sn, Al-Cd, and Al-Zn-Sn Alloys in Artificial Seawater}

\section{Studies on Aluminum Anode for Cathodic Protection (Part 10)}

Toshiyasu TAMURA, Eiichi SATO and Taijiro OKABE

The tests of galvanic anodes for cathodic protection were conducted on materials of $\mathrm{Al}-\mathrm{Zn}, \mathrm{Al}-\mathrm{Sn}$, $\mathrm{Al}-\mathrm{Cd}$, and $\mathrm{Al}-\mathrm{Zn}-\mathrm{Sn}$ alloys in an artificial seawater by using an apparatus for galvanostatic electrolysis. Corrosion aspects of the test pieces after 10-day immersion were analyzed by X-ray diffraction patterns and discussed by Hansen's Constitutional Diagram of Binary Alloys. The following conclusions were deduced from the change in anodic potential of aluminum alloys during 10 days and the current efficiency after that period: (1) Among Al-Zn alloys, Al-Zn (5.0-10.0) alloys showed good results. (2) None of Al-Sn and Al-Cd alloys were promising. (3) Among Al-Zn-Sn alloys, Al- Zn(3.0)-Sn (0.5) alloy and $\mathrm{Al}-\mathrm{Zn}(3.0)-\mathrm{Sn}(1.0)$ alloy had the best results.

\section{1. 緒言}

十分早な電極電位を持ち, 高出力電流があるアルミニ ウムは海水環境中の船舶あるいは海洋開発に使用される 鉄鋼構造物のカソード防食材としてもっとも重要であ る。海水中の腐食性環境に括いて，アルミニウムは表面 に酸化皮膜を作りやすいので，ある種の金属を添加する ことによって, その特性を取り除き, アルミニウムの性 能を生かすために, 前報1,2) にひきつついて, アルミニ

†流電陽極用アルミニウム合金に関する研究 (第10報), 前報(第 9 報)：金属表面技術，24，272（1973）

* 宇都宮大学工学部（杤木県宇都宮市石井町2753）

Faculty of Eng., Utsunomiya Univ.

**東北大学工学部（宮城県仙台市荒巻字青葉）

Faculty of Eng., Tohoku Univ.
ウム一亜鉛合金, アルミニウムースズ合金，アルミニウ ム一カドミウム合金およびアルミニウム一亜鉛一スズ合 金電極を試作して，流電陽極試験を行なった。

\section{2. 実 験 方 法}

\section{2-1 実験試料および電解液}

試料として使用したアルミニウム地金および亜鉛の化 学成分とスズ，カドミウムの純度はつぎのと拈りであ る。

\begin{tabular}{c|c|c|c}
\hline \multicolumn{4}{|c}{ アルミニウムの化学成分 $\%$} \\
\hline $\mathrm{Al}$ & $\mathrm{Si}$ & $\mathrm{Fe}$ & $\mathrm{Ca}$ \\
\hline 99.88 & 0.05 & 0.01 & 0.00 \\
\hline \multicolumn{3}{|c}{ スズ } & 試薬 1 級 (砂状) 関東化学(侏) \\
\hline \hline
\end{tabular}




\begin{tabular}{c|c|c|c|c}
\hline \hline \multicolumn{5}{|c}{ 亜鉛の化学成分 $\%$} \\
\hline $\mathrm{Pb}$ & $\mathrm{Cd}$ & $\mathrm{Cu}$ & $\mathrm{Fe}$ & $\mathrm{Al}$ \\
\hline 0.0009 & 0.0003 & 0.0001 & 0.0006 & $<0.0001$ \\
\hline
\end{tabular}

カドミウム 試薬 1 級 (粒状) 関東化学侏)

アルミニウムに亜鉛, スズ，カドミウムの二元 合 金 は, Al-Zn, Al-Sn, Al-Cd 系21種と三元合金として, $\mathrm{Al}-\mathrm{Zn}-\mathrm{Sn}$ 系 5 種を作製した。これらの合金は鋳放シで 熱処理はしていない。アルミニウム合金26種の試料番号 と化学成分值は表 1 に示した。

実験に用いた電解液は人工海水で，その組成はつぎと おりである。

表 1 アルミニウム合金の化学成分値

\begin{tabular}{|c|c|c|c|c|}
\hline No. & $\operatorname{Al}(\%)$ & $\operatorname{Zn}(\%)$ & $\operatorname{Sn}(\%)$ & $\mathrm{Cd}(\%)$ \\
\hline 1 & 98.88 & 1.0 & - & - \\
\hline 2 & 97.88 & 2.0 & 一 & - \\
\hline 3 & 96.88 & 3.0 & - & - \\
\hline 4 & 95.88 & 4.0 & - & - \\
\hline 5 & 94.88 & 5.0 & - & - \\
\hline 6 & 93.88 & 6.0 & - & - \\
\hline 7 & 92.88 & 7.0 & - & - \\
\hline 8 & 91.88 & 8.0 & - & - \\
\hline 9 & 90.88 & 9.0 & - & - \\
\hline 10 & 89.88 & 10.0 & - & - \\
\hline 11 & 99.88 & - & 0.01 & - \\
\hline 12 & 99.88 & - & 0.02 & - \\
\hline 13 & 99.88 & - & 0.05 & - \\
\hline 14 & 99.88 & - & 0.10 & - \\
\hline 15 & 99.88 & - & 0.50 & - \\
\hline 16 & 98.88 & - & 1.0 & - \\
\hline 17 & 96.88 & - & 3.0 & - \\
\hline 18 & 94.88 & - & 5.0 & - \\
\hline 19 & 99.88 & & & 0.01 \\
\hline 20 & 99.88 & & & 0.05 \\
\hline 21 & 99.88 & & & 0.10 \\
\hline 22 & 96.88 & 3.0 & 0.1 & - \\
\hline 23 & 96.88 & 3.0 & 0.5 & - \\
\hline 24 & 95.88 & 3.0 & 1.0 & - \\
\hline 25 & 94.88 & 5.0 & 0.1 & - \\
\hline 26 & 89.88 & 10.0 & 0.1 & - \\
\hline
\end{tabular}

表中の No. は以後各合金の試料番号とする。

\begin{tabular}{l|r||l|l}
\hline \hline \multicolumn{4}{c}{ 人工海水の組成 } \\
\hline $\mathrm{NaCl}$ & $245.3 \mathrm{~g}$ & $\mathrm{NaHCO}$ & $2.01 \mathrm{~g}$ \\
$\mathrm{MgCl}_{2} \cdot 6 \mathrm{H}_{2} \mathrm{O}$ & $111.1 \mathrm{~g}$ & $\mathrm{NaBr}$ & $1.01 \mathrm{~g}$ \\
$\mathrm{Na}_{2} \mathrm{SO}_{4}$ & $40.94 \mathrm{~g}$ & $\mathrm{H}_{3} \mathrm{BO}_{3}$ & $0.27 \mathrm{~g}$ \\
$\mathrm{CaCl}_{2}$ & $11.59 \mathrm{~g}$ & $\mathrm{SrCl}_{2} \cdot 6 \mathrm{H}_{2} \mathrm{O}$ & $0.42 \mathrm{~g}$ \\
$\mathrm{KCl}$ & $6.95 \mathrm{~g}$ & $\mathrm{NaF}$ & $0.03 \mathrm{~g}$ \\
\hline \hline
\end{tabular}

蒸留水を加えて 10 とする。つぎに $\mathrm{NaOH}$ で $\mathrm{pH} 8.2$ に 調製した。

表 2 試料 No. 1 26 の各種アルミニウム合金の流 電陽極試験結果

表中の実線は添加合金成分に分類してある。

点線は流電陽極試験を試料 No. 1〜 10, No. 11～20,

No. 21〜26の 3 回に分けて行なったため，通電電気量を それにより分けている。またそれそれの銅クーロメータ の陰極銅の增量は $5.7124 \mathrm{~g}, 5.6655 \mathrm{~g}$ と $5.6253 \mathrm{~g}$ である。

\begin{tabular}{|c|c|c|c|}
\hline $\begin{array}{c}\text { 試 料 } \\
\text { No. }\end{array}$ & $\begin{array}{c}\text { 陽 極 減 量 } \\
(\mathrm{g})\end{array}$ & $\begin{array}{c}\text { 通過電気量 } \\
(\mathrm{A} \cdot \mathrm{h})\end{array}$ & $\begin{array}{c}\text { 電流効率 } \\
(\%)\end{array}$ \\
\hline 1 & 6.8603 & \multirow{10}{*}{4.8165} & 23.8 \\
\hline 2 & 3. 6177 & & 45.4 \\
\hline 3 & 3.9023 & & 42.9 \\
\hline 4 & 3.8019 & & 43.8 \\
\hline 5 & 3.3318 & & 50.5 \\
\hline 6 & 3.4197 & & 49.5 \\
\hline 7 & 3.7364 & & 45.6 \\
\hline 8 & 3.6233 & & 47.5 \\
\hline 9 & 3.5076 & & 49.4 \\
\hline 10 & 3. 1156 & & 56.0 \\
\hline 11 & 1.8932 & \multirow{8}{*}{ 4. 7770} & 84.8 \\
\hline 12 & 1.9458 & & 82.5 \\
\hline 13 & 2.4390 & & 65.8 \\
\hline 14 & 3.6102 & & 44.4 \\
\hline 15 & 4. 2350 & & 37.9 \\
\hline 16 & 4.3530 & & 37.2 \\
\hline 17 & 5.2827 & & 31.2 \\
\hline 18 & 5.8459 & & 28.8 \\
\hline 19 & 1.8976 & & 84.6 \\
\hline 20 & 2.1086 & & 76.1 \\
\hline 21 & 2.0711 & & 76.9 \\
\hline 22 & 1.8579 & \multirow{5}{*}{ 4. 7430} & 87.7 \\
\hline 23 & 2. 2448 & & 72.5 \\
\hline 24 & 2. 1421 & & 76.7 \\
\hline 25 & 2. 2915 & & 72.0 \\
\hline 26 & 2.2750 & & 71.2 \\
\hline
\end{tabular}




\section{2一2 装置および剆定方法}

試料は径 $1.5 \mathrm{~cm}$ ，長芫約 $12 \mathrm{~cm}$ の鋳放材を用い，ビニ ルテープで被稪し，表面積 $20 \mathrm{~cm}^{2}$ とした。

試験槽は容積 $500 \mathrm{~m}$ ののプラスチック製容器を用いた。 陰極は材質がステンレス鋼の容器内壁に沿った円筒状 のもので, 表裏 2 面を含めて $700 \mathrm{~cm}^{2}$ の露出面皘がある。

定電流電解装置はダイオード使用の 定電流 装置 (150 $\mathrm{V} ， 0.5 \mathrm{~A}$ ) を使用した。

陽極（試験片）の試験部は水面または底面より少なく とも $10 \mathrm{~mm}$ 以上離した位置に固定し，槽の中央部に吊る

して試験を行なった。

試料の前処理と後処理はつぎのようにした。前処理は 試料表面をよく水洗 $\rightarrow$ セトン脱脂 $\rightarrow$ 乾燥後七ョウ量。 後処理は腐食生成物を水洗 $\rightarrow 4 \%$ 無水クロム酸および10 $\%$ \%酸溶液の $1 ： 1$ 混合液中に $80^{\circ} \mathrm{C} て ゙ 1 \min$ 浸七キ $\rightarrow$ 水洗 $\rightarrow$ 乾燥後七ョウ量。

測定方法は試験槽に人工海水を $500 \mathrm{~m} l$ 入れ, 各試料 と通過電気量を測定するため，銅電量計を回路に直列に 接続し, $20 \mathrm{~mA}$ の一定電流を定電流電解装置から通電寸 る。通電後, 高インピーダンス・精密級電位差計を用い てアノード電極電位を測定し, $2 \mathrm{~h}$ 後各アノードの電極
電位を測定した。試験期間中，人工海水は毎日 1 回，ア ノード電位を測定する $2 \mathrm{~h}$ 前に交換した。また測定はす べて室温で行なった。

測定時間は 240h (10 day) を基準とした。

試験終了後は試験槽から試料を, 銅電量計から陰極を 引き上げ, 後処理した後の試料の減量と銅電量計の陰極 の増量を測定した。

\section{3. 実験結果および考察}

電流効率の計算は次式により算出した。 電流効率 $(\%)=\frac{\text { 電量計から求めた電気量 }(\mathrm{A} \cdot \mathrm{h}) \times 100}{\text { 陽極減量 }(\mathrm{g}) \times \text { 理論発生電気量 }(\mathrm{A} \cdot \mathrm{h} / \mathrm{g})}$ ここで理論発生電気量は電気化学当量の巡数に相当す る。アルミニウム, 亜鉛, スズとカドミウムのアノード 反応をつぎのように考壳た。

$$
\begin{aligned}
& \text { アルミニウム } \mathrm{Al}=\mathrm{A}^{3+}+3 e^{-} \quad E=-1.90 \mathrm{~V} \\
& \text { (vs. S.C.E.) } \\
& \text { 亜鉛 } \quad \mathrm{Zn}=\mathrm{Zn}^{2+}+2 e^{-} \quad E=-1.00 \mathrm{~V} \text { (vs.S.C.E.) } \\
& \text { スズ } \mathrm{Sn}=\mathrm{Sn}^{2+}+2 e^{-} \quad E=-0.38 \mathrm{~V} \text { (vs.S.C.E.) } \\
& \text { カドミウム } \mathrm{Cd}=\mathrm{Cd}^{2+}+2 e^{-} \quad E=-0.64 \mathrm{~V} \\
& \text { (vs.S.C.E.) }
\end{aligned}
$$

これらからアルミニウム, 亜鉛, スズとカドミウムの a)

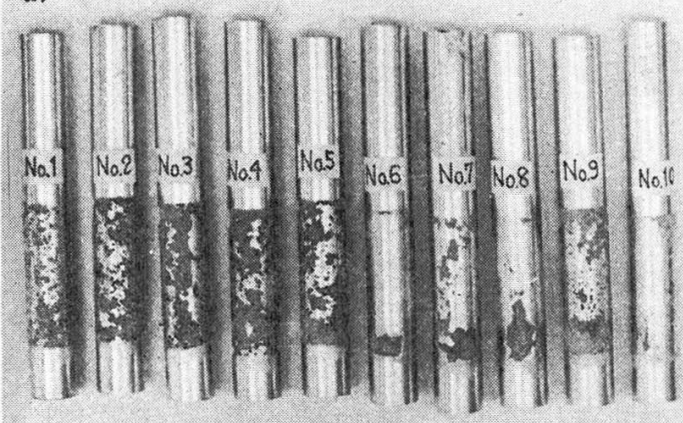

b)

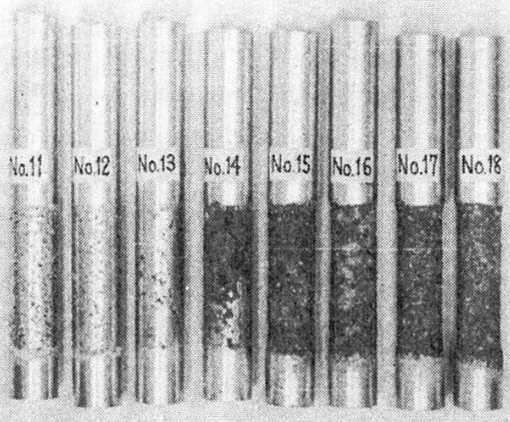

c)

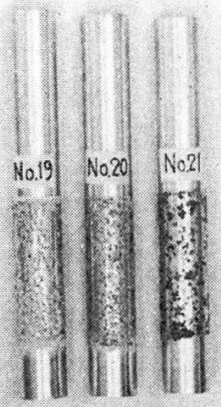

d)

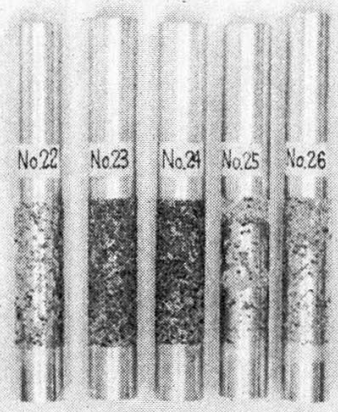

a) $\operatorname{Al}-\operatorname{Zn}(1.0 \sim 10.0 \%)$ 二元合金の腐食形態

c) $\mathrm{Al}-\mathrm{Cd}(0.01 \sim 0.10 \%)$ 二元合金の腐食形態 b） $\mathrm{Al}-\mathrm{Sn}(0.01 \sim 5.0 \%)$ の二元合金の窝食形態

d) $\mathrm{Al}-\mathrm{Zn}(3.0 \sim 10.0 \%)-\mathrm{Sn}(0.1 \sim 1.0 \%)$ の三元合金の腐食形態

写真 1 アルミニウム合金の流電陽極試験後の試料表面の腐食形態 
理論発生電気量は，それぞれ，2.98 $(\mathrm{A} \cdot \mathrm{h} / \mathrm{g})$, $0.82(\mathrm{~A} \cdot \mathrm{h} / \mathrm{g}), 0.452(\mathrm{~A} \cdot \mathrm{h} / \mathrm{g})$ と $0.477(\mathrm{~A} \cdot \mathrm{h} / \mathrm{g})$ である。

またアルミニウム合金の理論発生電気量 $E$ は, 合金成分に基ついて次式より求めた。

$E=(A \cdot x+B \cdot y+C \cdot z+\cdots \cdot \cdot) / 100$

$A, B, C \cdots \cdots=$ 合金成分の百分率； $x, y, z \cdots \cdots$ =合金の理論発生電気量

本実験でアルミニウムに添加した金属の含有量 $1.0 \%$ 未満のるのでは, アルミニウムの化学成分 \%はアルミニウムの純度 $(99.88 \%)$ をそのまま使 用して計算した。

表 2 にアルミニウム合金の流電陽極試験結果を示す。

写真 1 は流電陽極試験後の試験片の表面状態を表わし ている。a) は試料 No. 1 10の Al (99.88\%) -Zn (1.0

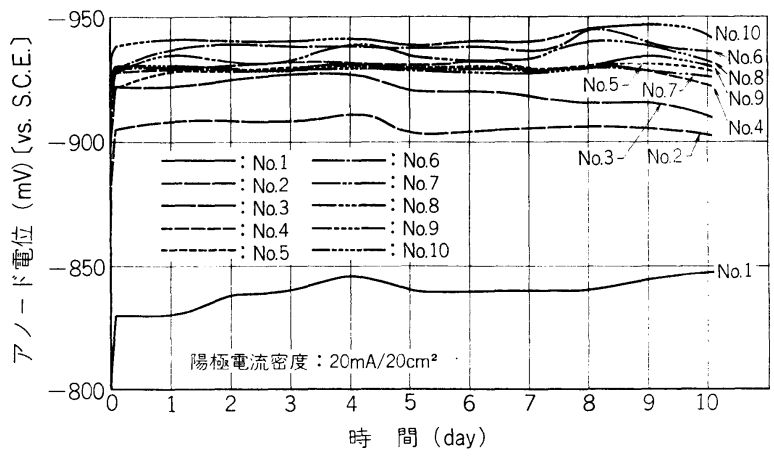

図 1 人工海水中の $\mathrm{Al}-\mathrm{Zn}(1 \sim 10 \%)$ 合金のアノード電極 電位の経時変化

〜 10.0\%) 合金, b) はNo.11〜18の Al (99.88\%) -Sn (0.01〜 5.0\%) 合金, c) は No. 19〜21のAl (99.88\%)$\mathrm{Cd}(0.01 \sim 0.10 \%)$ 合金, d) はNo. 22 26のAl (99.88\%)

表 3 アルミニウム合金の X 線回析による各格子面の強度と (111）面之（200）面の面間隔

\begin{tabular}{|c|c|c|c|c|c|c|}
\hline \multirow{2}{*}{$\begin{array}{l}\text { 強度と面間隔 } \\
\text { 試料番号 } \\
\text { No. }\end{array}$} & \multicolumn{3}{|c|}{$\begin{array}{l}\text { 面指数 }(\mathrm{hkl}) \text { の } \\
\text { 回折強度 } \mathrm{I} / \mathrm{I}_{1}\end{array}$} & \multicolumn{2}{|c|}{$\begin{array}{c}\text { 格子面間隔 } \\
\text { d ( (A) }\end{array}$} & \multirow{2}{*}{ 備 } \\
\hline & 111 & 200 & $220 \quad 311 \mid$ & 111 & 200 & \\
\hline 1 & 100 & 93.4 & 14.733 .8 & 2.337 & 2.020 & $\mathrm{Zn}$ は検出されず \\
\hline 2 & 88.6 & 100 & 11.339 .8 & 2.336 & 2.02 .5 & $"$ \\
\hline 3 & 100 & 96.2 & 19.239 .7 & 2.336 & 2.022 & $"$ \\
\hline 4 & 100 & 78.7 & 25.230 .3 & 2.337 & 2.022 & $"$ \\
\hline 5 & 100 & 72.6 & 19.531 .3 & 2.335 & 2.024 & " \\
\hline 6 & 100 & 64.8 & 322.535 .7 & 2.335 & 2. 021 & " \\
\hline 7 & 100 & 84.1 & 20.631 .8 & 2.334 & 2.021 & " \\
\hline 8 & 100 & 87. 4 & 15.029 .3 & 2. 333 & 2.020 & " \\
\hline 9 & 100 & 79.9 & 18.028 .8 & 2.328 & 2.021 & " \\
\hline 10 & 100 & 27.1 & 120.330 .2 & 2.330 & 2.020 & " \\
\hline 11 & 84.0 & 100 & 11.235 .3 & 2.. 337 & 2.022 & $\beta-S n$ は検出されず \\
\hline 12 & 100 & 93.6 & 6.038 .8 & 2.335 & 2.021 & " \\
\hline 13 & 70.7 & 100 & 10.124 .8 & 2.335 & 2.024 & " \\
\hline 14 & 38.0 & 100 & 11.321 .4 & 2.333 & 2.022 & $"$ \\
\hline 15 & 57.3 & 100 & 8.320 .8 & 2.335 & 2.024 & $\beta-\mathrm{Sn}$ のわずかな検出 \\
\hline 16 & 100 & 87.2 & 9.943 .0 & 2.338 & 2.024 & $\beta-\mathrm{Sn}$ の検出 \\
\hline 17 & 100 & 77.6 & 14.532 .9 & 2.335 & 2.021 & $"$ \\
\hline 18 & 100 & 77.3 & 315.335 .3 & 2.334 & 2.024 & $"$ \\
\hline 19 & 100 & 97.1 & 12.634 .3 & 2.335 & 2.023 & Cd は検出されず \\
\hline 20 & 82.9 & 100 & 25.646 .3 & 2.335 & 2.022 & " \\
\hline 21 & 60 & 100 & 12.521 .5 & 2. 334 & 2.022 & " \\
\hline 22 & 100 & 98.7 & 731.349 .3 & 2. 337 & 2. 022 & $\mathrm{Zn}, \beta-\mathrm{Sn}$ は検出されず \\
\hline 23 & 100 & 83.1 & 16.934 .3 & 2. 334 & 2. 021 & " \\
\hline 24 & 100 & 97.5 & 512.437 .0 & 2.335 & 2. 018 & $\beta-\mathrm{Sn}$ はわずかに検出 \\
\hline 25 & 100 & 84.7 & 23.531 .8 & 2.334 & 2.022 & $\mathrm{Zn}, \beta-\mathrm{Sn}$ は検出されず \\
\hline 26 & 100 & 82.3 & 328.529 .1 & 2.336 & 2.020 & " \\
\hline
\end{tabular}

$\mathrm{CuK} \alpha_{1}$ (Niフィルタ) 使用
$-\operatorname{Zn}(3.0 \sim 10.0 \%)-\operatorname{Sn}(0.1 \sim$ $1.0 \%)$ 合金である。

$\mathrm{Al}-\mathrm{Zn}$ 二元系合金の流電陽極 試験片 No. 1〜No.10 のアノー ド電極電位の経時変化を図 1 亿 示す。図は横軸に時間 (day), 縦軸にアノード電極電位 $\mathrm{mV}$ （vs. S.C.E.）を表わす。以後図 3 まで同様に表わしている。 覀鉛の添加合金では，アノー ド電極電位は亜鉛添加量の増加 にしたがって卑になっている。 添加量 $1 \%$ (No.1) 合金は他の 合金とかけはなれた貴の電位に あり, $-840 \mathrm{mV}$ (vs. S.C.E.)で 電流効率は24\%であった。各合 金の電流効率は表 2 にかかがて ある。添加量 $2 \%$ か9\%の合 金（No. 2〜9）までのアノード 電極電位は -900〜 -940 mV (vs.S.C.E.)で, 電流効率は40〜 50\%であった。とくにNo.6， No. 8 と No.10の合金はアノー ド電極電位も No. 1 5, No. 7 に比べて卑で, 一 $940 \mathrm{mV}$ (vs. S. C. E.), 電流効率も5 $0 \%$ 近 になっている。試験後引きあげ られた試料の表面状態はいずれ る均一な腐食状態ではなかっ た。この結果をHansen の Al$\mathrm{Zn}$ 二元合金状態図 ${ }^{3)}$ 之 X 線回 折から考察すると, この実験で 


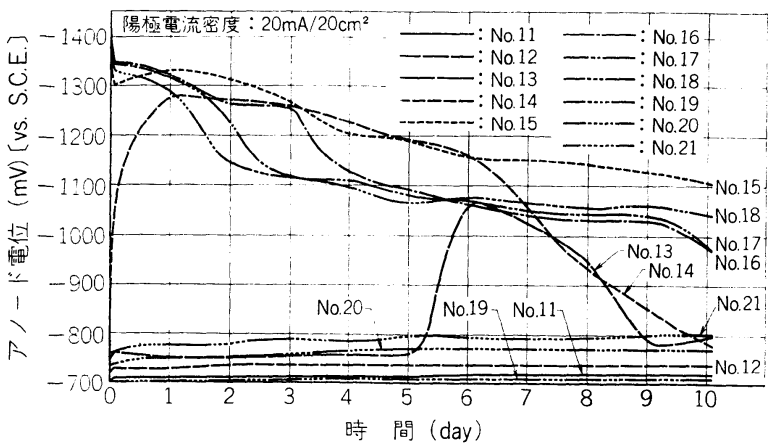

図 2 人工海水中の $\mathrm{Al}-\mathrm{Sn}(0.01 \sim 5.0 \%)$ 合金之 $\mathrm{Al}-\mathrm{Cd}$ $(0.01 \sim 0.1 \%)$ 合金のアノード電極電位の経時変化
た。

Hansen の状態図 ${ }^{3)}$ と X線回折から, Al-Sn二 元合金は共晶反応の合金であるが，スズの添加量 がきわわて少ない状態（試料 No.11とNo.12 にあ たる）のため, A1 地金の特性だけが流電陽極試験 に表われ，アルミニウム特有な酸化皮膜で括括わ れて,アノード電極電位は貴であるが, $\mathrm{A} 1$ 合金が適 当に溶解するために電流効率当高い。スズが0. 05 \%から $0.1 \%$ 合金(試料 No.13と No.14) では 初晶のスズが A1 地金の格子面 (111)をみだし, (111)面より溶解しやすい(200)面4) が多く表われ てくる。試料 No.13 の合金は No.14の合金に比 べて (111) 面が多いので, 初期の試験段階では,
試作した $\mathrm{Al}-\mathrm{Zn}$ 二元合金は表 3 に示したと特り，アル ミニウムに亜鉛が10\%まで置換固溶したものであった。 アルミニウムに亜鉛を添加した重量パーセントが少ない 状態（試料No.1）では，アルミニウム地金が腐食形態を 支配し，アノード電極電位は貴で，わずかな添加金属で ある覀鉛がアルミニウム合金の孔食を促進させるため， 電流効率(\%)がとくに低くなったと考えられる。しかし 亜鉛がアルミニウムと置換固溶した量が増加(試料No. 2 〜10)するにしたがって, Al-Zn 合金の表面を括拐ってい る酸化皮膜は，部分的に亜鉛の酸化皮膜で沶拉われてい るので, アルミニウムの表面酸化皮膜より $\mathrm{Cl}^{-}$イオンに 対して耐食性が弱いとされていることから，アノード電 流が酸化皮膜の欠陥部を通して流出しやすくなるので， アノード電極電位は亜鉛の添加量が増えるにしたがって 卑になる。これらの実験結果はアルミニウムに亜鉛が置 換固溶したために説明できると考学られる。

$\mathrm{Al}-\mathrm{Sn}$ 二元系合金の流電陽極試験片 No.11〜18 のアノ 一ド電極電位の経時変化を図 2 に示す。

スズ0.01\%，0.02\%，0.05\% と $0.10 \%$ 添加した合金 (No.11, No.12, No.13 と No.14) 湴鉛合金と同様 に試験開始後からアノード電位の変化はほとんどしない で, 亜鉊 10\%添加した合金よりも貴な電位, 一 700 $\sim-800 \mathrm{mV}$ (vs. S.C.E.) を示している。電流効率 はNo. 11〜13までが 85〜65\%で, No. 14が44\%で あった。添加量 $0.5 \%$ 以上のスズ合金 (No. 15, 16，17と18）では，亜鉛10\%添加した合金（No. 10）より卑な電極電位を示しているが，実験開始 から10day 後の電極電位は250mV (vs. S.C.E.) も 貴になっており，変動も大さかった。No. 15〜 18のアノード電極電位はー975〜ー $1100 \mathrm{mV}$ (vs. S.C.E) であり，電流効率は 39～28\% であった。 写真から試料の表面状態をみると, No. 11 と 12 はかなり厚い酸化皮膜におおわれて, 孔食がおこ っている。No. 17 と 18 は比較的均一腐食であっ
スズの添加量が少ないのでアノード電極電位は貴な值を 示すが，電解時間の経過とともに，(200）面が溶出して No. 14 と同じ経過をたどってアノード電極電位に達し, 最終的には No.13 No.14 万アノード電極電位は貴に なる。試料No.15では共晶のスズの影響を受けて, 各格 子面は規則正しい配列に移行し，またNo.16から No. 18 ではA1-Sn合金に含まれるSnが多くなるにしたがって， 合金表面の $\mathrm{Sn}$ の晶出部分の酸化皮膜は $\mathrm{Al}$ よりできにく いため, 試験開始初期ではアノード電極電位は卑である が，電解時間の経過ととるに溶出しアノード電極電位は 貴になり，電流効率もだんだん悪くなると考えられる。

A1-Cd二元系合金の流電陽極試験片 No. 19〜21 のア ノード電極電位の経時変化をスズ合金と同じ図（図 2) に示し,スズ0.01\%,0.02\%合金 (No.11と12) と同じと ころにアノード雪極電位 $(-700 \sim-800 \mathrm{mV}$ vs. S.C.E.) があった。またカドミウム合金は $\mathrm{Al}-\mathrm{Zn}$ 合金と同様に カドミウムの添加量の増加にしたがって卑な電位になっ た。電流効率は80\%を示した。表面状態はアルミニウム にスズ(0.01\%，0.02\%) を添加した試料（No.11，12） のように表面が厚い酸化皮膜に拈执われて孔食が起こっ ている。

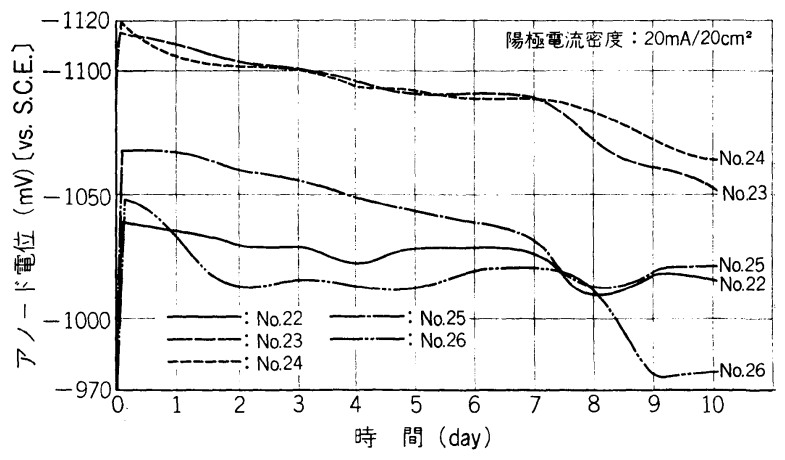

図 3 人工海水中の $\mathrm{Al}-\mathrm{Zn}(3 \sim 10 \%)$ - $\mathrm{Sn}(0.1 \sim 1.0 \%)$ 合金のアノード電極電位の経時変化 
Hansen の状態図 ${ }^{3)}$ から Al-Cd 合金は包晶反応ででき る合金である。しかしアルミニウム地金に添加した Cd の量がいずれる少ないために，X線回折でも検出されず (表 3参照), 試料No.19 から21にかけて孔食が激しく発 生し，アノード電極電位も卑となり，電流効率も高くな る。

いまカドミウム $0.01 \%$ か $0.1 \%$ をでの添加範囲では， $\mathrm{X}$ 線回折からアルミニウム地金の格子面 (111)をみだし 格子面(200)が多く表われたため, 格子面(111)より格子 面 (200) の孔食電位が杽4) なことから, 試料 No.19から No.21 までの順序でアノード電極電位も卑となり, 電流 効率も高くなると推定した。

Al-Zn-Sn の三元系合金の流電陽極試験片 No. 22〜26 のアノード電極電位の経時変化を図 3 に示す。

アルミニウムに亜鉛とスズを添加した合金では，亜鉛 の添加量が 少なくスズの添加量の多い合金 (No. 23 と No. 24）のほうがスズの添加量に比べて亜鉛の添加量の 多い合金 (No.25とNo.26)よりアノード電極電位は卑で, -1050〜-1070 mV (vs. S.C.E.) であった。No. 25 と No.26のアノード電極電位は試験開始後急激に卑になる が, 電解時間の経過後, 徐々に貴になり，10day 後では とくにNo.26はその差が $200 \mathrm{mV}$ (vs. S.C.E.) にもなっ た。アノード電極電位はー970〜ー1020mV (v.s.S.C.E.) の範囲にある。電流効率は No. 22，23，24，25 と26はそ れぞれ88\%，73\%，77\%，72\%と71\%であり，表面状態 はNo. 23 と No. 24 がもっとも均一腐食を示した。
三元系合金の陽極性能が良かったことについては目下 検討中である。

\section{4. 結 論}

アルミニウム合金のアノード電極電位の 10 day 後の 経時変化と電流効率から

(1) アルミニウム一亜鉛合金では，No. 5〜No.10 は良 好な陽極性能を示した。

（2）アルミニウムースズ合金は陽極性能が良好なるのは なかった。

(3) アルミニウムーカドミウム合金は陽極性能としても っとも悪かった。

(4) アルミニウム一亜鉛一スズ合金では, No.23 No. 24が陽極性能がもっとも良かった。

終わりに実験を担当してくださった大出雅章君と小沼 博君に厚く感謝いたします。（1973-3ー29 受理）

\section{文献}

1）佐藤栄一, 田村寿康, 久保田実, 岡部泰二郎, 金属 表面技術，23，662（1972）

2 ）佐藤栄一, 田村寿康, 岡部泰二郎, 金属表面技術, 23, 669 (1972)

3) M. Hansen, Constitution of Binany Alloys. p. 77, p. 135, p. 149 McGraw-Yill (1558)

4) I. Garz, W. Schatt, Z. Physik. Chem., 240, 373 (1969)

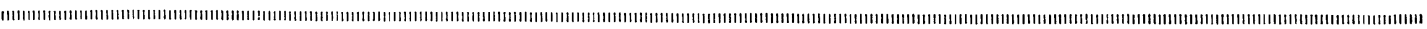

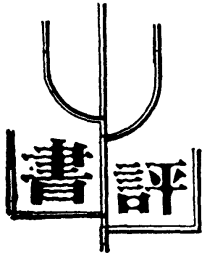

砥粒加工法は人造研削材の発展とともに, 日進月歩で これに関連する学術用語や慣用語が多数あって中には同 じ内容で異なった語句が用いられたり，あるいはその逆 もあるなどと，日ごろこの方面の専門辞典が出版される ことを望まれていた。砥粒加工研究会が編集された本書 は, 日・英・独・仏・露対訳解説付きで, 研削と研摩の 技術用語を専門的に集成した好著である。

用語の選定は CIRP の Dictionary of Production
砥粒 加工研 究 会 編

\section{研削 ・ 研摩技術用語辞典}

\section{A 5 判, 163 ページ, 工業調査会, 定価 1,600円}

Engineering, 第 2 巻」その他の便覧, 辞典, 学術誌お よび J I Sなど約40種のものから行なわれ，だいたい CIRP 方式で分類し，同義語を整理して，重要と思われ る約 500 語を選定している。とくに主要項目に説明図解 入りで印刷されていることが特徵で, 研究者はもらろん 広く生産加工技術にたずさわる人たちに有用の辞典であ る。（後藤健一） 